Agro-Science Journal of Tropical Agriculture, Food, Environment and Extension Volume 16 Number 2 (May 2017) pp. $38-45$

ISSN 1119-7455

\title{
INFLUENCE OF INORGANIC FERTILIZER AND SPACING ON GROWTH AND YIELD OF TWO MAIZE CULTIVARS UNDER Striga hermonthica INFESTATION
}

\author{
${ }^{*}$ Garba, Y. ${ }^{2}$ Abubakar, H.N. and ${ }^{3}$ Aliyu, I. \\ ${ }^{1}$ Department of Crop Production, Ibrahim Badamasi Babangida University Lapai. Niger State. \\ ${ }^{2}$ National Cereals Research Institute P.M.B.8 Badeggi. Niger State, Nigeria. \\ ${ }^{3}$ Department of Crop production, University of Maiduguri, Nigeria. \\ E-mail: yah_gar@yahoo.com
}

\begin{abstract}
Field experiment was conducted during the 2013 rainy season at Lapai and Mokwa in the Southern Guinea savanna of Nigeria, to evaluate the reactions of maize cultivars to nitrogen and intra-row spacing in a Striga hermonthica infested field. The treatments consisted of two maize cultivar (Local (kabako) and SAMMAZ 16), four levels of nitrogen fertilizer $\left(0,60,120\right.$ and $\left.180 \mathrm{~kg} \mathrm{~N} \mathrm{ha}^{-1}\right)$ and three intra-row spacing $(20,25$ and $30 \mathrm{~cm})$. The treatments were factorial combined and laid out in a Randomized Complete Block Design and replicated three times. Results revealed that plant height, number of leaves and days to $50 \%$ anthesis of Local maize cultivars responded significantly with $60 \mathrm{~kg} \mathrm{~N} \mathrm{ha}^{-1}$ at 9 WAS. $180 \mathrm{~kg} \mathrm{~N} \mathrm{ha}^{-1}$ and $25 \mathrm{~cm}$ intra-row spacing in combination with SAMMAZ 16 recorded the highest grain yield, 100 grain weight, stover yield, shelling percentage and harvest index. The local cultivars supported greater Striga infestation at $20 \mathrm{~cm}$ intra-row spacing and $180 \mathrm{~kg} \mathrm{~N} \mathrm{ha}^{-1}$ was found remarkable for Striga suppression at 9 WAS in this study. From these findings, it could be concluded that the above combinations can be used for effective management of Striga hermonthica for optimum yield of maize.
\end{abstract}

Key words: spacing, maize cultivar, nitrogen fertilizer, Striga hermonthica

\section{INTRODUCTION}

Maize (Zea mays L.) belongs to the family Poaceae and has its centre of origin in Mexico (Chhidda et al., 2003). It is one of the oldest and most important crops in the world with multiple uses (Monlruzzaman et al., 2009). It is ranked third as most important cereal in the world after wheat and rice in terms of grain production (Asghar et al., 2010). Morris (2001) reported that maize is the world's most widely distributed crop from the tropics to the temperate zone. It is produced on nearly 100 million hectares in developing countries, with almost $70 \%$ of the production in the developing world coming from low and lower middle income countries (FAOSTAT, 2010). Global average yield in 2009 was estimated at 5 t/ha (Edgerton, 2009), while yield obtained in developing countries are still behind world average (Pixley et al., 2009). Maize grain yields in Nigeria varied from $0.8 \mathrm{t} / \mathrm{ha}$ to $8.0 \mathrm{t} / \mathrm{ha}$ depending on cultivars used, ecology, farming system adopted and management practices involved (Olakojo and Olaoye,
2007). In Nigeria, two types of maize cultivars are grown, the yellow and white and due to its adaptability, it is grown as rain fed and irrigated. Some of the major producing states in Nigeria are Adamawa, Bauchi, Borno, Yobe, Jigawa, Gombe, Taraba, Plateau, Sokoto, Kebbi, Katsina, Nasarawa, Niger and Zamfara (FORAMINIFERA, 2013).

The parasitic Striga spp is said to be a treat to farmers in maize producing belts and is becoming endemic. Matata et al. (2011) reported that the most economically important Striga (Witch weed) species infesting food crops in Africa are Striga hermonthica (Del.) Benth, Striga asiatica (L.) Kuntze and Striga gesnerioides (Willd.). Among the three Striga parasitic weed species, S. hermonthica is reported to be the species that causes the greatest damage to cereal crops causing huge losses in grain yield (Atera et al. 2013). Liman and Mathew (2013) reported one of the characteristics of the parasitic witch weed to be its damages to host plant before emergence above

Please cite as: Garba, Y., Abubakar, H.N. and Aliyu, I. (2017). Influence of inorganic fertilizer and spacing on growth and yield of two maize cultivars under Striga hermonthica infestation. Agro-Science, 16 (2), 38-45. DOI: https://dx.doi.org/10.4314/as.v16i2.6 
Influence of Inorganic Fertilizer and Spacing on Growth and Yield of Two Maize Cultivars

ground. The economic losses due to Striga spp., according to Runo et al. (2012) are enormous with cereal food crops such as maize, sorghum, millet, wheat and upland rice. Globally, it was reported that several million hectares of arable land are infected by Striga species and causes huge losses to farmers in Sub-Saharan Africa (SSA) (Parker, 2008). The weed is capable of reducing yields by between 30 and $70 \%$ and sometimes results in total crop failure especially in the endemic areas of maize production (Anjorin et al., 2013). The devastating damages caused by Striga infestation has forced maize farmers to abandon their farm lands to Striga, or forced change to production of less susceptible crops (Olakojo and Olaoye, 2007). The decline in soil fertility has been reported to have favored Striga proliferation (Kanampiu et al., 2003; Oswald, 2005). Several control measures of Striga spp. have been recommended such as manual hand pulling, use of catch and trap crops, use of $\mathrm{N}$ fertilizer, application of post emergence herbicide, cereal-legume rotation and host plant resistance (Dugje et al., 2010). To this effect, technique of adopting different levels of nitrogen fertilizer and intra-row spacing were evaluated in order to determine how Striga can be minimized to obtain reasonable maize yield. The objective of this study is to evaluate the response of maize cultivars to nitrogen fertilizer levels and intra-row spacing under artificial Striga hermonthica infestation.

\section{MATERIALS AND METHODS}

Field trials were carried out in two locations - Lapai and Mokwa, Niger State in the Southern Guinea Savanna of Nigeria-during the 2013 cropping season.(June-September). Lapai and Mokwa lies between latitude $9^{0} 2^{\prime} \mathrm{N}$ and $9^{0} 18^{\prime} \mathrm{N}$, longitude $6^{0}$ $34^{\prime} \mathrm{E}$ and $5^{\circ} 04^{\prime} \mathrm{E}$ in the Southern Guinea Savanna of Nigeria respectively (Adetimirin et al., 2000 and Isah et al., 2011). Zubairu and Jibrin (2014) reported that, Niger State is located in the Southern Guinea Savanna zone of Nigeria with mean annual precipitation of $1,300 \mathrm{~mm}$ taken from a long record of 50 years. The highest mean monthly rainfall is September with almost $3000 \mathrm{~mm}$, and the rainy season starts on average in April and lasts between 190-200 days. Composite soil samples were collected from the experimental fields at different portion and analyzed and the result was tested to be sandy loam with $\mathrm{pH}$ of 5.46 and 5.44 in Lapai and Mokwa respectively. The treatments consisted of factorial combination of two Maize cultivars - Local (Kabako) and SAMMAZ 16 (Improved Striga resistant cultivar). Four levels of Nitrogen fertilizer in the form of Urea $\left(0,60,120\right.$ and $\left.180 \mathrm{~kg} \mathrm{~N} \mathrm{ha}^{-1}\right)$ and spacing $(20,25$ and $30 \mathrm{~cm})$ was used and arranged in a randomized complete block design replicated three times. The plant population in this study is $6,666.67$, $5,333.33$ and 4,444.44 per hectare representing 20, 25 and 30 intra-row spacing at $75 \mathrm{~cm}$ inter-row spacing. Each plot size contained 5 ridges at $3.75 \mathrm{~m}$ by $3 \mathrm{~m}$ $\left(11.25 \mathrm{~m}^{2}\right)$ and one seed each per hole was sown. SAMMAZ 16 was obtained from the Institute for Agricultural Research (IAR) Zaria, Kaduna state while the Local cultivar was obtained from a maize grower in the study area. Sowing and harvesting of maize cultivars was conducted in June and October, 2013 respectively. Striga hermonthica was artificially inoculated uniformly in each hole using coca-cola bottle cap of sand and Striga mixture before sowing (Ezeaku and Gupta, 2004).

Weeding was done manually with hoe at 3 weeks after sowing (WAS) and subsequently with hand pulling, this was to ensure survival of emerged Striga seeds and the test crop. Side placement of half dose of nitrogen fertilizer $(0,60,120$ and $180 \mathrm{~kg} \mathrm{~N}$ $\mathrm{ha}^{-1}$ ) in the form of Urea (46\%) together with $60 \mathrm{~kg}$ ha $^{-1}$ each of $\mathrm{P}_{2} \mathrm{O}_{5}$ and $\mathrm{K}_{2} \mathrm{O}$ were applied three weeks after sowing, second half dose of $\mathrm{N}$ fertilizer was later applied by side placement at 6 weeks after sowing (WAS). A treatment $\left(0 \mathrm{~kg} \mathrm{~N} \mathrm{ha}{ }^{-1}\right)$ was established to serve as a control. At harvest, the cobs were plucked, dehusked and then weighed. The cobs were dried, threshed and winnowed to obtain clean grains. The data collected were subjected to analysis of variance (ANOVA) using statistical analysis software (SAS, 2002) at 5\% level of probability.

\section{RESULTS AND DISCUSSION}

Effect of nitrogen fertilizer and spacing on the growth parameters of maize under Striga infestation in the 2013 rainy season.

The effect of Nitrogen and Spacing on the growth of maize cultivars showed a significant response to treatments. There was a significant difference in plant height, number of leaves and $50 \%$ anthesis at 9 WAS (Table 1). Plant stand count and days to 50\% silking observed in this study was not significantly different at 9 WAS in both locations. Plant height at 9 WAS showed significant differences in both locations, such that the Local cultivars produced significantly taller plants than SAMMAZ 16 cultivars. The difference in plant height could be linked to genetic make-up inherent of the cultivars. This finding corroborates that of Majambu et al. (1996) who attributed the 
Garba, Y. Abubakar, H.N and Aliyu, I.

differences in growth indices of crops to the genetic constitution and Raemaekers (2001) who also reported that local cultivars are taller than the improved cultivars. Number of leaves and days to 50 $\%$ anthesis at Lapai and Mokwa differed significantly such that the Local cultivar produced more numbers of leaves with early days to anthesis. The reason could be attributed to difference in growth characters as may be influenced by the genetic characteristics of the maize cultivars. This is in line with the study of Enujeke (2013) who attributed an increase in number of leaves to growth characters engineered by the genetic make-up of the plants. There was an Interaction between maize cultivars and nitrogen fertilizer in terms of plant height in Lapai at 9 WAS. The result shows that Local cultivar significantly produced taller plants at $60 \mathrm{~kg} \mathrm{~N}^{-1}$ which is similar to the result obtained at $120 \mathrm{~kg} \mathrm{~N}^{-1}$ while SAMMAZ 16 produced shorter plants consistently at all levels of nitrogen application, although at par with the local cultivar at $0 \mathrm{~kg} \mathrm{~N} \mathrm{ha}^{-1}$ (Table 2). However, the significant increase observed with maize cultivars in terms of plant height under Striga infestation could be attributed to the importance of $\mathrm{N}$ application which plays a vital role in Striga suppression which resulted in adequate crop growth and development. This result was similar to the findings of Prasad and Singh (1990) who observed a significant increase in growth parameters of maize with increase in fertilizer application. The interaction between nitrogen and spacing on number of leaves at 9 WAS in Lapai differed significantly. The result shows that spacing of $20 \mathrm{~cm}$ produced the higher number of leaves which was obtained with application of $180 \mathrm{Kg} \mathrm{N}^{-}$ ${ }^{1}$, and the result is at par with other treatments. The spacing of $20 \mathrm{~cm}$ at $0 \mathrm{Kg} \mathrm{N} \mathrm{ha}{ }^{-1}$ produced the lowest number of leaves (Table 3 ). This could be attributed to insufficient nutrient status of the soil which might have stimulated the growth of Striga that lead to lower number of leaves due to its devastating effect. Our findings is in consonance with the observations of Gacheru and Rao (2011) who reported that declining soil fertility increases Striga infestation due to lack of N. Franke et al. (2006) also reported Striga abundance is clearly favored by low soil fertility. The interaction of cultivars and nitrogen fertilizer levels on days to $50 \%$ silking at Lapai was highly significant $(\mathrm{p}<0.01)$ (Table 4$)$. The shortest days to silking was recorded at $0 \mathrm{~kg} \mathrm{~N}^{-1}$ in both locations (Table 4). All other combinations on this parameter produced similar shortest days to silking in both locations, but at par with the Striga resistant cultivar
(SAMMAZ 16) at Mokwa in all levels of $\mathrm{N}$ evaluated. The results on days to $50 \%$ silking is in conformity with the report of Anjorin et al. (2013) who indicated that maize cultivars respond significantly to different levels of $\mathrm{N}$ especially for days to $50 \%$ silking.

Effect of nitrogen fertilizer levels and intra-row spacing on yield parameters of maize cultivars during the 2013 rainy season

Yield parameters of maize cultivars such as grain yield, 100grain weight, stover yield, shelling percentage and harvest index differed significantly. SAMMAZ 16 maize cultivar consistently produced the highest result in both locations in terms of grain yield, 100 grain weight, stover yield, shelling percentage and harvest index, but the result at Lapai in terms of stover yield and harvest index was not significant (Table 5). This result agreed with the report of Kureh et al. (2003) who reported Striga tolerant maize cultivars supported lower Striga incidence and infestation. Application of $\mathrm{N}$ at different levels played a role in terms of yield. The use of $180 \mathrm{~kg} \mathrm{~N} \mathrm{ha}^{-1}$ consistently produced the highest grain yield, 100 grain weight, stover yield, shelling percentage and harvest index. However, the lowest result obtained with all yield parameters in this study was recorded in plots without fertilizer application $\left(0 \mathrm{~kg} \mathrm{~N} \mathrm{ha}^{-1}\right)$. The highest grain yield recorded with SAMMAZ 16 suggested that the improved cultivar utilizes greater amount of soil resources than the Local cultivar, this agreed with the finding of Tiamiyu (2011) who reported that improved cultivars have good conversion ability from source to sink resulting to high yield. Spacing had no significant effect on stover yield and harvest index, but significant differences were observed with grain yield and shelling percentage at Lapai and 100grain weight at Mokwa such that $25 \mathrm{~cm}$ intra-row spacing was found adequate for the higher yield obtained with SAMMAZ 16 than with the Local cultivar. These increases in yield might be due to optimum spacing with less Striga infestation. This is in conformity with Iken and Amusa (2004) who reported greater yield at $25 \mathrm{~cm}$ intra-row and $75 \mathrm{~cm}$ inter-row spacing at one plant per stand. In Table 6, the interaction of cultivars and nitrogen on grain yield was highly significant $(\mathrm{p}<0.01)$ at Lapai, and $\mathrm{p}<0.05$ at Mokwa such that SAMMAZ 16 produced the highest grain yield with application of $180 \mathrm{~kg} \mathrm{~N}$ $\mathrm{ha}^{-1}$ though similar result were obtained at Mokwa favoring the improved cultivar. Application of $180 \mathrm{~kg}$ 
Influence of Inorganic Fertilizer and Spacing on Growth and Yield of Two Maize Cultivars

$\mathrm{N}$ ha ${ }^{-1}$ produced the highest stover yield in Lapai and shelling percentage in both locations in combination with SAMMAZ 16. The 100 grain weight in combination with the Local cultivar at $180 \mathrm{~kg} \mathrm{~N} \mathrm{ha}^{-1}$ was the highest. The highest result obtained in grain yield, stover yield and shelling percentage with SAMMAZ 16 was a demonstration of the superiority of the improved cultivar over the Local cultivar and the higher dose of $\mathrm{N}$ at $180 \mathrm{~kg} \mathrm{~N}$ ha $^{-1}$ which played a greater role of Striga suppression to obtain higher yield due to less Striga damage to host plant. This revealed the importance of N in Striga control and maize high yield. This result confirmed the report of Esilaba et al. (2000) who reported that application of nitrogenous fertilizer increases grain yield of the host crop under Striga pressure. The Local (Kabako) cultivar showed the lowest values in all yield parameters evaluated in this study

Table 1: Effect of nitrogen levels and intra-row spacing on growth parameters of maize cultivars under Striga hermonthica infestation at 9 WAS in the 2013 rainy season.

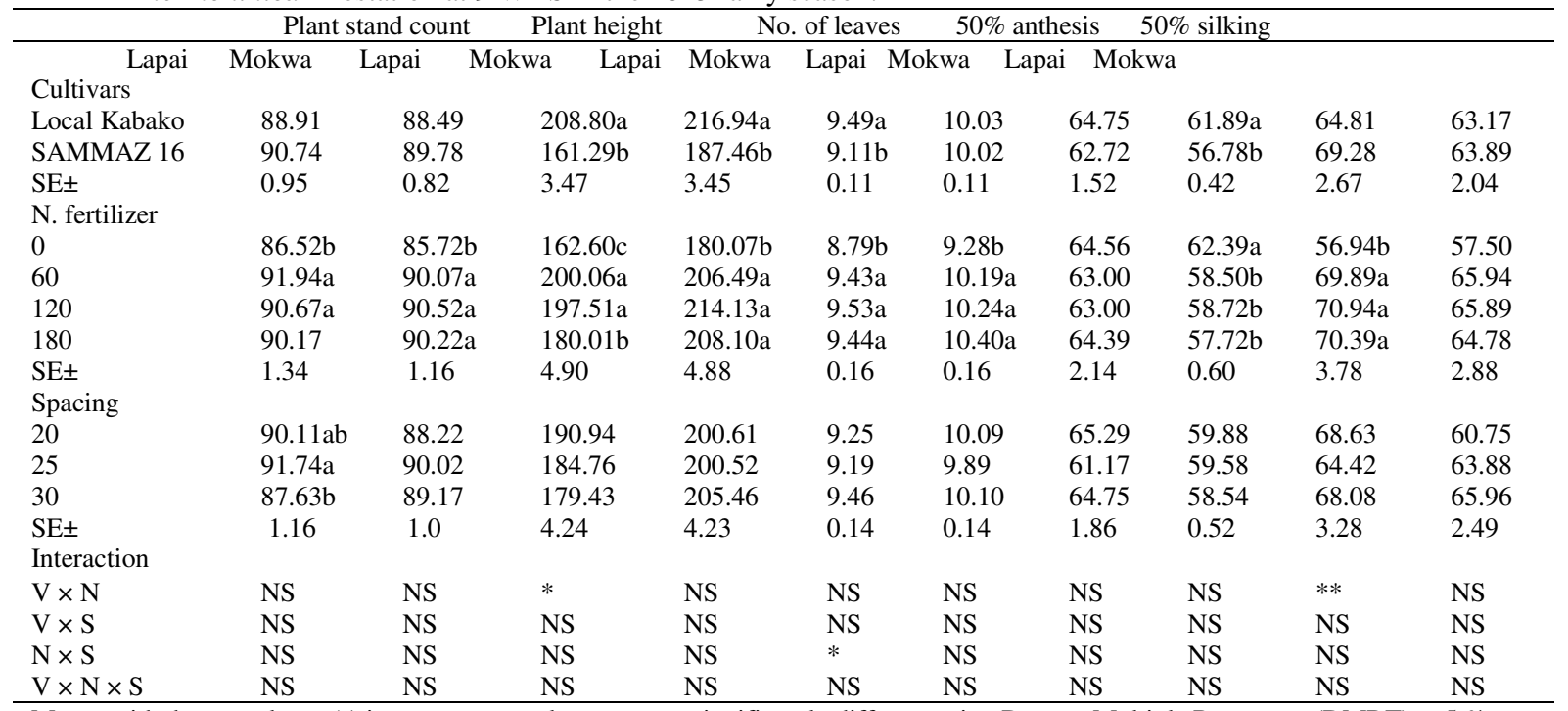

Means with the same letter (s) in a treatment column are not significantly different using Duncan Multiple Range test (DMRT) at $5 \%$ level of probability. NS=not significant at $5 \%$ level, ${ }^{*}=$ significant at $5 \%$ level, $* *=$ highly significant at $1 \%$ level.

Table 2: Interaction of nitrogen fertilizer rate and intra-row spacing on plant height under Striga hermonthica infestation in Lapai at 9 WAS during the 2013 rainy season.

\begin{tabular}{|c|c|c|c|c|}
\hline \multirow[b]{2}{*}{$\begin{array}{l}\text { Treatment } \\
\text { Cultivars }\end{array}$} & \multicolumn{3}{|c|}{ Nitrogen fertilizer rate $\left(\mathrm{Kg} \mathrm{ha}^{-1}\right)$} & \multirow[b]{2}{*}{180} \\
\hline & 0 & 60 & 120 & \\
\hline $\begin{array}{l}\text { Local } \\
\text { (Kabako) }\end{array}$ & $171.4 \mathrm{bc}$ & $234.7 \mathrm{a}$ & $226.9 \mathrm{a}$ & $202.1 \mathrm{ab}$ \\
\hline $\begin{array}{l}\text { SAMMAZ } 16 \\
\text { SE } \pm\end{array}$ & $153.8 \mathrm{c}$ & $165.4 \mathrm{c}$ & $\begin{array}{l}168.1 \mathrm{c} \\
0.69\end{array}$ & $157.9 \mathrm{c}$ \\
\hline
\end{tabular}

Table 3: Interaction of nitrogen fertilizer rate and intrarow spacing on number of leaves under Striga hermonthica infestation in Lapai at 9 WAS during the 2013 rainy season.

\begin{tabular}{llll}
\hline & & Intra-row spacing $(\mathrm{cm})$ & \\
\cline { 3 - 3 } $\begin{array}{l}\text { Treatments } \\
\text { Nitrogen } \\
\text { fertilizer } \\
\left(\mathrm{Kg} \mathrm{ha}^{-1}\right)\end{array}$ & 20 & & \\
0 & & & \\
60 & $8.13 \mathrm{~d}$ & $8.97 \mathrm{c}$ & $9.27 \mathrm{a}-\mathrm{c}$ \\
120 & $9.43 \mathrm{a}-\mathrm{c}$ & $9.33 \mathrm{a}-\mathrm{c}$ & $9.53 \mathrm{a}-\mathrm{c}$ \\
180 & $9.47 \mathrm{a}-\mathrm{c}$ & $9.40 \mathrm{a}-\mathrm{c}$ & $9.73 \mathrm{ab}$ \\
$\mathrm{SE} \pm$ & $9.97 \mathrm{a}$ & $9.07 \mathrm{bc}$ & $9.30 \mathrm{a}-\mathrm{c}$ \\
\hline & & 0.27 & \\
$\begin{array}{l}\text { Means with the same letter (s) are not significantly different at 5 } \\
\%\end{array}$ &
\end{tabular}


Garba, Y. Abubakar, H.N and Aliyu, I.

Table 4: Interaction of nitrogen fertilizer rate and intra-row spacing on days to $50 \%$ silking under Striga hermonthica infestation in Lapai during the 2013 rainy season.

\begin{tabular}{|c|c|c|c|c|}
\hline \multicolumn{5}{|c|}{ Varieties } \\
\hline Treatment & Local (Kabako) & SAMMAZ 16 & Local (Kabako) & SAMMAZ 16 \\
\hline Nitrogen fertilizer. & & & & \\
\hline 0 & $42.33 b$ & $71.56 \mathrm{a}$ & $48.11 \mathrm{~b}$ & $66.89 \mathrm{ab}$ \\
\hline 60 & $71.33 \mathrm{a}$ & $68.44 \mathrm{a}$ & $68.44 \mathrm{a}$ & 63.44ab \\
\hline 120 & $72.56 \mathrm{a}$ & $69.33 \mathrm{a}$ & $68.33 \mathrm{a}$ & 63.44ab \\
\hline 180 & $73.00 \mathrm{a}$ & $61.78 \mathrm{ab}$ & $67.78 \mathrm{a}$ & $61.78 \mathrm{ab}$ \\
\hline $\mathrm{SE} \pm$ & & 5.35 & & 4.07 \\
\hline
\end{tabular}

Means with the same letter (s) are not significantly different at $5 \%$ level of probability using Duncan Multiple Range test (DMRT).

Table 5: Response of yield parameters of maize cultivars to nitrogen levels and intra-row spacing in the 2013 rainy season.

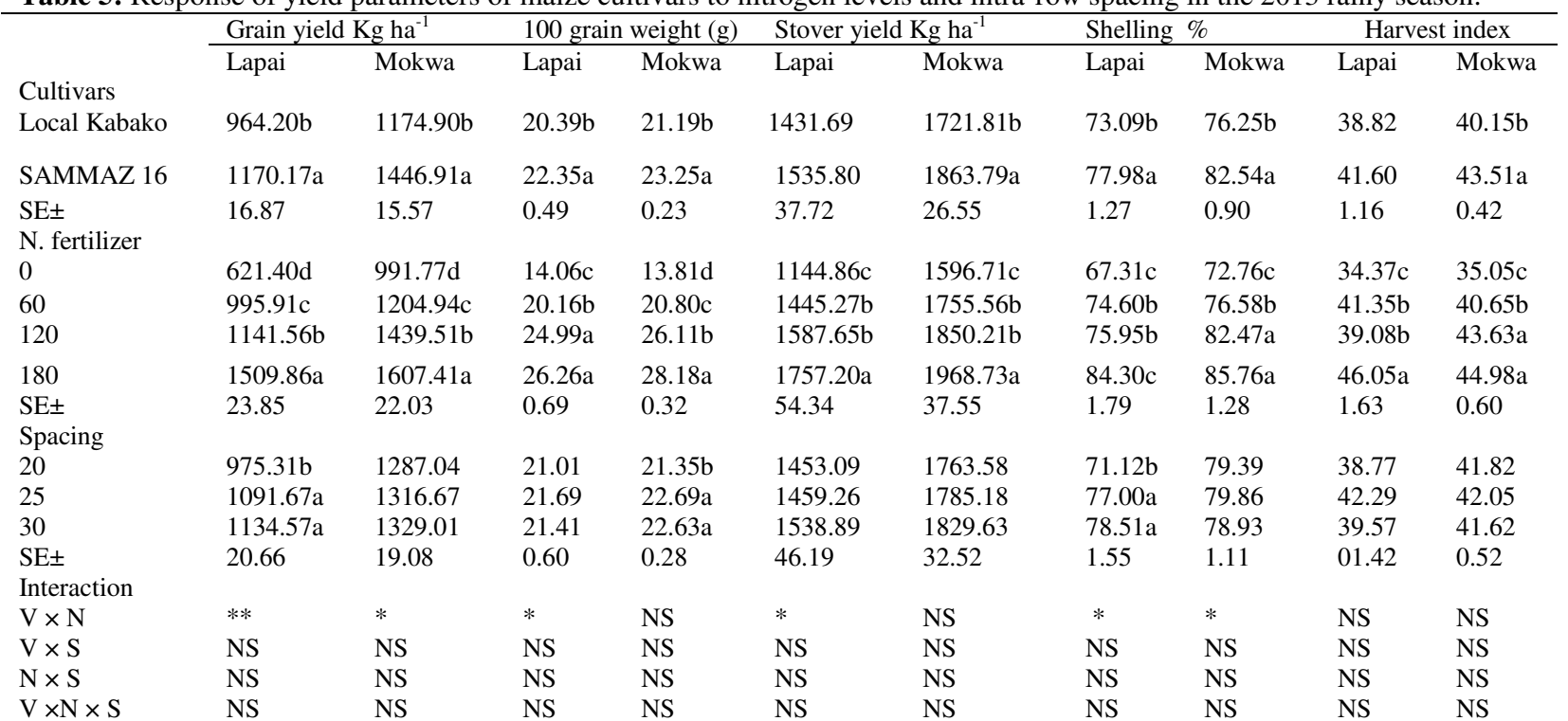

Means with the same letter (s) in a treatment column are not significantly different using Duncan Multiple Range Test (DMRT) at $5 \%$ level of significance. NS $=$ not significant, $*=$ significant at $5 \%$ level, $* *=$ highly significant at $1 \%$ level

Effect of nitrogen fertilizer levels and spacing on Striga parameters at 9 WAS during the 2013 rainy season.

Maize cultivars responded to Striga shoot count and incidence in both locations. The local cultivar which is susceptible to Striga hermonthica infestation in both locations supported the highest number of Striga shoot count and incidence (Table7), while SAMMAZ 16 , because of its superiority over the local cultivar supported lower Striga shoot count and incidence in both locations. This result might be due to the superiority of the improved cultivar over the susceptible Local maize cultivar. The result agreed with the report of Menkir and Kling (2007) who reported susceptible cultivars supported the highest number of emerged Striga. Application of nitrogen fertilizer played a vital role in Striga suppression in both locations plots with no fertilizer application $(0$ $\mathrm{kg} \mathrm{N} \mathrm{ha}{ }^{-1}$ ) had the highest Striga shoot count and incidence at both locations at 9 WAS while $180 \mathrm{~kg} \mathrm{~N}$ $\mathrm{ha}^{-1}$ was found to be adequate as there was less Striga shoot count, while Striga incidence was reduced by $120 \mathrm{~kg} \mathrm{~N} \mathrm{ha}^{-1}$. This result reflect the report of Kamara et al. (2008b) who reported higher dosages of nitrogen fertilizer rate and organic materials can reduce $S$. hermonthica damage in maize and a high level of nitrogen application above $120 \mathrm{~kg} \mathrm{~N} \mathrm{ha}^{-1}$ would be required to achieve a significant reduction in Striga emergence (Franke et al., 2006). Intra-row spacing of $20 \mathrm{~cm}$ statistically produced the highest Striga incidence at $0 \mathrm{~kg} \mathrm{~N} \mathrm{ha}^{-1}$ in Lapai. Increase in number of Striga incidence could be as a result of closer spacing which makes it easier for Striga to host plant attachment. The result agreed with the findings of Ibikunle et al. (2009) who reported that intra-row spacing of $20 \mathrm{~cm}$ produced the highest Striga emergence counts in a field trial. 
Table 6: Interaction of nitrogen fertilizer levels and intra-row spacing on yield parameters of maize cultivars in the 2013 rainy season at Lapai and Mokwa.

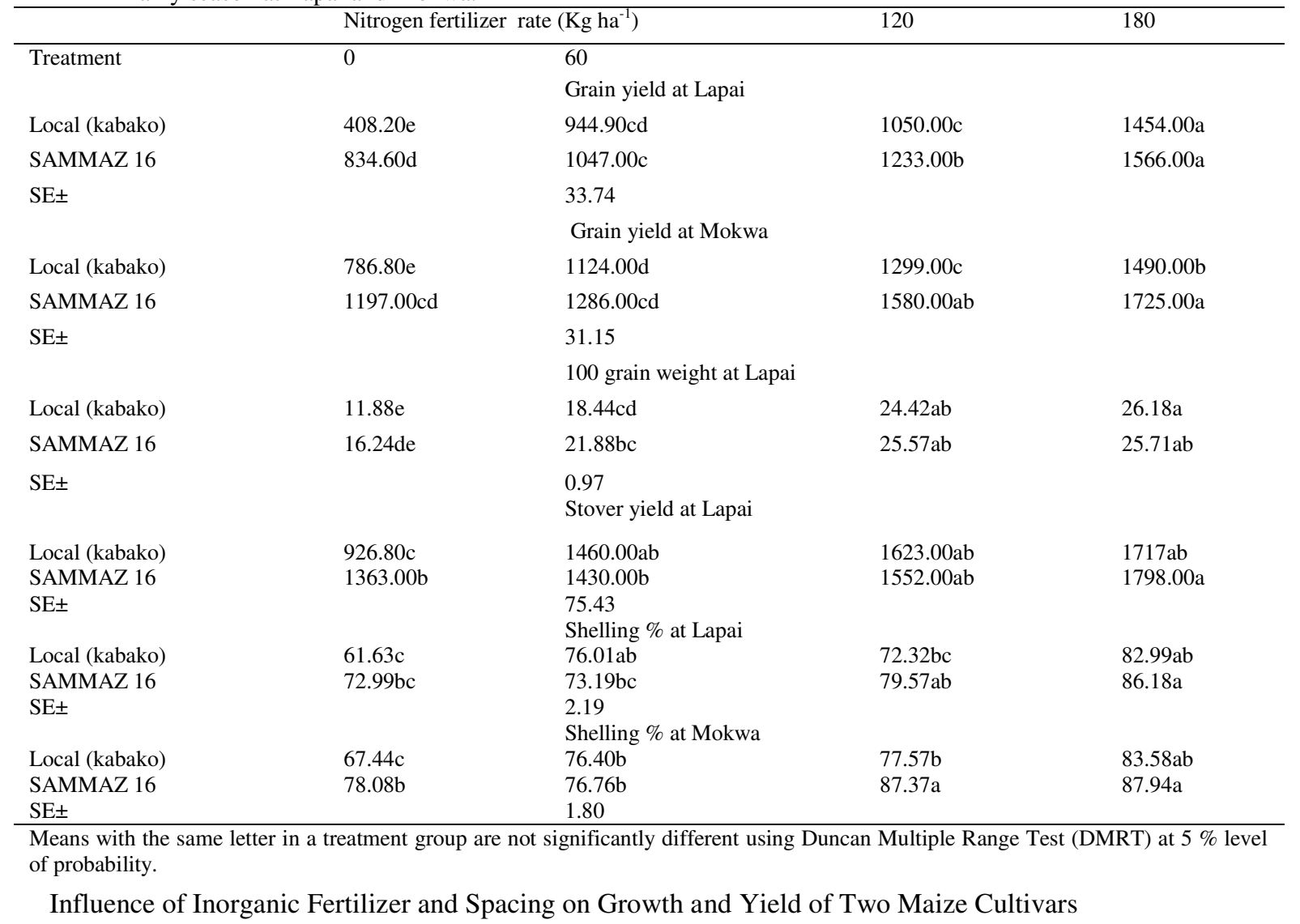

Table 7: Effect of nitrogen fertilizer levels and intra-row spacing on Striga shoot counts and Striga incidence in the 2013 rainy season at Lapai and Mokwa.

\begin{tabular}{|c|c|c|c|c|}
\hline \multirow[b]{3}{*}{ Cultivars } & \multicolumn{2}{|c|}{ Striga shoot count } & \multirow{2}{*}{$\begin{array}{l}\text { Striga incidence } \\
\text { Lapai }\end{array}$} & \multirow[b]{2}{*}{ Mokwa } \\
\hline & Lapai & Mokwa & & \\
\hline & & & & \\
\hline Local cultivars & $6.69 \mathrm{a}$ & $8.39 \mathrm{a}$ & $4.56 \mathrm{a}$ & $5.47 \mathrm{a}$ \\
\hline SAMMAZ 16 & $3.78 \mathrm{~b}$ & $5.25 \mathrm{~b}$ & $2.75 b$ & $3.97 \mathrm{~b}$ \\
\hline $\mathrm{SE} \pm$ & 0.31 & 0.45 & 0.16 & 0.20 \\
\hline \multicolumn{5}{|c|}{ Nitrogen $\mathrm{kg} \mathrm{N} \mathrm{ha}^{-1+}$} \\
\hline 0 & $10.17 \mathrm{a}$ & $11.61 \mathrm{a}$ & $6.50 \mathrm{a}$ & $8.28 \mathrm{a}$ \\
\hline 60 & $4.89 \mathrm{~b}$ & $8.11 \mathrm{~b}$ & $3.39 \mathrm{~b}$ & $5.22 \mathrm{a}$ \\
\hline 120 & $3.61 \mathrm{c}$ & $5.17 \mathrm{c}$ & $2.56 \mathrm{c}$ & $3.67 \mathrm{c}$ \\
\hline 180 & $2.78 \mathrm{~d}$ & $2.39 \mathrm{~d}$ & $2.17 \mathrm{c}$ & $1.72 \mathrm{~d}$ \\
\hline $\mathrm{SE} \pm$ & 0.44 & 0.63 & 0.23 & 0.41 \\
\hline \multicolumn{5}{|l|}{ Spacing $(\mathrm{cm})$} \\
\hline 20 & 5.58 & 6.71 & $4.08 \mathrm{a}$ & 4.96 \\
\hline 25 & 4.79 & 7.17 & $3.42 \mathrm{~b}$ & 4.96 \\
\hline 30 & 5.33 & 6.58 & $3.46 \mathrm{~b}$ & 4.58 \\
\hline $\mathrm{SE} \pm$ & 0.38 & 0.55 & 0.20 & 0.35 \\
\hline \multicolumn{5}{|l|}{ Interaction } \\
\hline $\mathrm{V} \times \mathrm{N}$ & NS & NS & NS & NS \\
\hline $\mathrm{V} \times \mathrm{S}$ & NS & NS & NS & NS \\
\hline $\mathrm{N} \times \mathrm{S}$ & NS & NS & NS & NS \\
\hline $\mathrm{V} \times \mathrm{N} \times \mathrm{S}$ & NS & NS & NS & NS \\
\hline
\end{tabular}


Garba, Y. Abubakar, H.N and Aliyu, I.

\section{CONCLUSION}

From the Information gathered in this study, an appropriate use of $180 \mathrm{~kg} \mathrm{~N} \mathrm{ha}^{-1}$ for SAMMAZ 16 at $25 \mathrm{~cm}$ intra-row spacing and one seed per hole is adequate to minimize Striga infestation in maize field. SAMMAZ 16 supported lower Striga infestation compared to the local cultivar (Susceptible to Striga hermonthica) which recorded the highest number of Striga infestation. However, going by the results obtained in this study, farmers could be advised to use the above combination and $\mathrm{N}$ rates for optimum growth and yield of maize under Striga hermonthica infestation.

\section{REFERENCE}

Adetimirin, V.O., Aken'Ova, M.E and Kim, S.K. (2000). Effect of Striga hermonthica on yield components in maize. Journal of Agricultural Science, Cambridge, $135185-191$

Anjorin. F.B., Olakojo, S.A and Aduloju, M.A. (2013). Testing of Striga resistant composite maize cultivars for response to two levels of nitrogen fertilizer uptake. Journal of plant Science vol. 7 (9): $432-437$

Asghar, A,. Ali, A., Sayed, H.W., Khaliq, T and Abid, A.A. (2010). Growth and yield of maize (Zea mays) cultivers affected by NPK application in different proportion. Pakistan Journal of Science, 62 (4): 211.

Atera, E.A., Ishii, T., Onyango, J.C., Itoh, K and Azuma, T. (2013). Striga infestation in Kenya: Status,distribution and management options sustainable agriculture research., 2 (2): 99- 108.

Chhidda, S., Prem, S and Rajbir, S. (2003). Maize (Zea mays). Modern techniques of raisin field crops. Second edition. Vijay Primlani for Oxford and IBH publishing co. PVT Ltd New Delhi: p. 84- 111.

Dugje, L.Y., Ekeleme, F., Kamara, A.Y., Menkir, A., Chikoye, D and Omoidui, L.O. (2010). Field evaluation of Sorghum cultivars to Striga hermonthica infestation in North eastern Nigerian Savannas. Nigeria journal of weed science., 23: 1-11

Edgerton, M.D. (2009). Increasing food productivity to meet global needs for food, feed and fuel. Plant Physiology 149 7 -13

Enujeke, E.C. (2013). Effects of cultivars and spacing on growth characters of hybrid maize. Asian Journal of Agriculture and Rural Development, 3(5) 296 -310

Esilaba, A.O., Reda, F., Ransom, J.K., Bayu, W., Woldewahid, G and Zemichael, B. (2000). Integrated nutrient management strategies for soil fertility improvement and Striga control in Northern Ethiopia. African Crop Science Journal, 8 $403-410$.

Ezeaku,I.E and Gupta, S.C. (2004). Development of Sorghum populations for resistance to Striga hermonthica in Nigeria Sudan Savanna. African journal of Biotechnology vol. 3 (6) 324 -329

FAOSTAT. (2010). Food and Agricultural Organization of the United Nations (FAO), FAO Statistical Database, 2010, from http://faostat.fao.org

FORAMINIFERA (2013). Foramera market research: Milling in Nigeria; The Opportunities retrieved from www.foramfera.com 5/5/2013.

Franke, A.C., Ellis-Jones, J., Tarawali, G., Schulz, S., Hussaini, M.A., Kureh, I., White, R., $\quad$ Chikoye, D., Douthwaite, B., Oyewole. B.D and Olanrewaju, A.S. (2006). Evaluating and scaling-up integrated Striga hermonthica control technologies among farmers in northern Nigeria. Crop Protection 25: 868- 878

Gacheru, E and Rao, M.R. (2011) Managing Striga infestation on maize using organic and inorganic nutrient sources inWestern Kenya. International Journal of Pest Manage 47: 233-239.

Ibikunle, O.A.A., Menkir, A., King, J.G and mith, M.A.K. (2009). Evaluating intra- row spacing to optimize Techniques for artificial infestation of Striga hermonthica (DEL.) Screening for resistance in maize. Maydica 54: 47-53

Iken, J.E and Amusa, N.A. (2004). Maize research and production in Nigeria. AfricaJournal of Biotechnology, 3 (6) 302-307

Isah, K.M., Lagoke, S.T.O., Tswanya, M.N and Garba, Y. (2011). On-Farm evaluation of rotating groundnut and cassava intercrop with host crop maize for Striga hermonthica management in the Southern Guinea Savana of Nigeria. Journal of Arid Agriculture, 20: $53-60$

Kamara, A.Y., Ellis-Jones, J., Amaza, P., Omoigui, L.O., Helsen, J., Dudje, I.Y., Kamai, N., Menkir, A and White, R.W (2008b). A participatory approach to increasing productivity of maize through Striga hermonthica control in northeast Nigeria. Experimental Agriculture, 44: 349 -364

Kanampiu, F.K., Kabambe,V., Massawe, C., Jasi, L., Friesen, D., Ransom, J.K and Gressel, J (2003). Multi-site, multi-season field tests demonstrate that herbicide seed-coating herbicide-resistance maize controls Striga spp. and increases yields in several African countries. Crop Protection, 22: 697- 706.

Kureh, I., Chikoye, D., Emechebe, A.M., Hussaini, M.A., Kormawa, P., Schulz, S., Ellis-Jones, J., Franke, L and Odunze, A.C. (2003). Reduction of Striga hermonthica parasitism on maize using host plant resistance, $\mathrm{N}$ fertilization and rotation with legume trap-crops. African Crop science conference proceedings, 6: 67-171.

Liman Rabba Muhammad and Mathew Ahmed (2013). Incorporation of melon shell at different stages of land preparation in the management of Striga hermonthica (Del.) Benth in maize (Zea mays L.) International Journal of Scientific Research in Environmental Sciences (IJSRES), 1(5): 71-77 
Influence of Inorganic Fertilizer and Spacing on Growth and Yield of Two Maize Cultivars

Majambu, I.S., Ogunlella, V.B and Ahmed, M.K. (1996). Responses of two Okro (Abelmoschus esculentus $(L)$ Moench) cultivars to fertilizer growth and nutrient concentration as influenced by nitrogen and phosphorus applications. Fertilizer Research, 8 (3): 297-306.

Matata, P.Z., Gama, B.M., Mbwaga, A., Mpanda, M and Byamungu, D.A. (2011). Effect of Sesbania sesban fallows on Striga infestation and maize yield in Tabora Region of Western Tanzania. Journal of Soil Science and Environmental Management, 2 (10):311-317

Menkir, A and Kling, J.G. (2007). Response of recurrent selection for resistance to Striga hermonthica (Del.) Benth in a tropical maize population. Crop Science, 47: 674-684

Monlruzzaman., Rahman, M.S., Karim, M.K and Alam, Q.M. (2009). Agro-economic Analysis of maize production in Bangladesh: A Farm Level Study. Bangladesh Journal of Agricultura Research, 34 (1): $15-24$

Morris, M.L. (2001). Assessing the benefits of international maize breeding research. An Overview of the global maize Impact study. In: pingali, P. L (ed).

Olakojo, S.A and Olaoye, G. (2007). Response of maize (Zea mays L) to nitrogen fertilizer formulations under Striga lutea (LOUR) artificial infestation. Tropical and subtropical Agroecosystems, 7: 21-28

Oswald, O. (2005). Striga control-technologies and their dissemination. Crop Protection, 24:333 - 342.
Parker, C. (2008). Observations on the current status of Orobache and Striga problems Worldwide. Pest Management Science, 65: 453-459.

Pixley, K., Banziger, M., Cordova, H., Dixon, J., Kanampiu, F., Srivastava, A., Waddington, S and Warburton, M. (2009). Past and future innovations of tropical maize improvement. CIMMYT. Report, Mexico.

Prasad, K and Singh, P. (1990). Response of promising rain fed maize cultivars to $\mathrm{N}$ application in North-West Himalayas region. Indian Journal of Agricultural Science. 75- 77

Raemaekers, R.H. (2001) Crop Production in Tropical Africa. Royal Library Albert Brussels 46-58.

Runo, S., Macharia, S., Alakonya, A., Machuka, J., Sinha, N and Schol. J. (2012). Striga parasitizes transgenic hairy roots of Zea mays and provides a toolfor studying plant-plant interactions. Plant Methods, 20: $8-20$

Statistical Analysis System (SAS) (2003). SAS Institute Inc. Cary, NC., USA.

Tiamiyu, R.H., Ahmed, H.G and Muhammad, A.S.(2012). Effect of sources of organic manure on growth and yield of okra (Abelmoschus esculentus L.) in Sokoto, Nigeria. Nigeria journal of Basic and Applied Science 20 (3): 213-216

Zubairu, S. U. and Jibril, H. M. (2014). Yam Dioscorea spp.) Farmers' Adaptation to climate change in some selected local government areas in Niger State, Nigeria. International Journal of Applied Biological Research, 6 (2): 46 - 55 